How to cite this article:

Ibrahim, H,. Zulkafli, A. H., \& Jabeen, G. (2020). Board education, growth and performance of family CEO listed firms in Malaysia. International Journal of Banking and Finance, 15(2), 25-46. https://doi.org/10.32890/ijbf2020.15.2.2

\title{
Board Education, Growth and Performance of Family CEO Listed Firms in Malaysia
}

\author{
${ }^{1}$ Haslindar Ibrahim \\ ${ }^{2}$ Abdul Hadi Zulkafli \\ ${ }^{3}$ Gul Jabeen \\ School of Management \\ ${ }^{3}$ Universiti Sains Malaysia, Malaysia \\ ${ }^{1}$ Corresponding author: haslindar@usm.my; \\ 2hadi_zml@usm.my; \\ 33uljäbeen04@gmail.com
}

\section{A R T I C L E I N F O}

Article history:

Received 29 November 2019

Revised 3 February 2020

Accepted 17 February 2020

Published 31 July 2020

JEL Code is G32, G34

Keywords:

Board professional qualification, board degree, growth, family CEO firms.
A B S T R A C T

This paper examines the relationship between board education, board size, growth, ownership and firm performance of family CEO and nonfamily CEO listed firms in Malaysia. A sample of 37 firms and data were collected over a period of five years from 2012 to 2016. The 37 samples of family firms were subdivided into family CEO (21), and non-family CEO (16) firms. The independent variables were board education as measured by the proportion of board degrees (BDEG) and the proportion of board professional qualifications (BPRO), board size (BSIZE), growth, and ownership. Meanwhile, firm performance was measured by using return on equity (ROE) and return on assets (ROA). The findings showed that there was a significant difference 
between family $\mathrm{CEO}$ and non-family CEO firms at a five percent level for board professional qualifications confirming that altruism and nepotism were observed among family members which supported the argument of characteristics of nepotism such as granting jobs to family members regardless of merit. In addition, this study also found board professional qualifications as significant but negatively related to external firm performance in family CEO firms. This showed that board education has not really been emphasized among board members. Besides, growth has significant influence on family firm performance which is evidently reflected in their contribution to the country's GDP.

\section{Introduction}

Family businesses are predominantly affluent companies that have flourished through wealth generation. Asian literatures have shown that family firms in many countries, including Australia, Taiwan, Hong Kong, Singapore and China, have performed well (Filatotchev, Lien \& Piesse, 2005; La Porta, Lopez-De-Silances \& Shliefer, 1999). In addition, a study conducted by Faccio, Lang \& Young (2002) in 13 Western European countries verified that at a 20 percent cut-off level, 44.3 percent are family owned firms. However, the percentage of family firms increases to 57.2 percent when they exclude Ireland and the United Kingdom in the sample. Similarly, the study conducted by Claessens, Djankov and Lang (2000) on nine East Asian countries at the 20 percent cut off-level revealed that the percentage of family firms in the sample statistically increased from 38.29 percent to 58.68 percentwhen Japan was excluded from the sample. Apparently, Japan has the largest share of widely held family firms at 79.8 percent based on the 20 percent cut-off level. In Malaysia, about 70 percent of listed firms are family businesses and they are the major contributors to the country's Gross Domestic Product (GDP) (Amran \& Ahmad, 2010).

Meanwhile, corporate governance emphasizes on the collective action taken when a firm faces problems with alternative stakeholders. In the process 
of addressing problems or conflicts, firms often rely on large shareholders who have significant ownership and control rights to influence decisions. In the global corporate world, large shareholders with significant controlling power are commonly found to be family firms. Apparently, family controlled ownership in firms are typical and common in worldwide corporations. Apart from the performance between family firms and non-family firms, there were numerous studies carried out to examine their comparison (Anderson \& Reeb, 2003; Miller \& Le Breton-Miller, 2006; Villalonga \& Amit, 2006; Ibrahim \& Samad, 2011; Amran \& Ahmad 2010). Even though family firms contribute significantly to the Malaysian economy, they are found to lack independence and internal control. Therefore, these problems need to be addressed in family firms as family businesses are governed by family traits, which do not exist in other businesses (Mishra, Randoy \& Jenssen, 2001).

Despite the importance of corporate governance on firm performance, research on Malaysian family firms seems to lag behind. Admittedly, there is too little empirical evidence to prove that Malaysian family firms perform better than non-family firms. For instance, Ibrahim and Lau (2018) revealed from a study that board size, independent directors and duality do show a strong relationship with firm performance. Thus, this study would like to focus more on the academic background or qualifications among board members especially in family firms. The board qualifications come entrusted with a wide range of observable or unobservable capabilities in this knowledge overflow modern period which appear to be a critical issue related to firm performance. To ensure high corporate governance quality of firms through identification and measurement of its capabilities, board members especially the chief executive officer (CEO) has to obtain educational qualifications which include a degree(s) or postgraduate recognition for better and reliable communication with the stakeholders (Bhagat, Bolton \& Subramanian, 2010). According to Gottesman and Morey (2006a), superior intelligence can be measured with educational qualifications where managers with a higher level of education often perform better than managers with a low level of education. Furthermore, investigations by Ujunwa, Nwakoby, and Ugbam (2012) found that firms with board members holding $\mathrm{PhD}$ degrees have positive relationships and that such firms perform better.

However, generally it is important to remember that superior managerial skills are not always obtained from a high level of academic qualifications. In terms of distinction, soft skills like entrepreneurial and leadership skills are often developed from non-academic related activities. In fact, there are also findings which show fast-growing and high-performing firms that are founded and managed by average-educated individuals. These contradicting results from previous studies complicate the importance of board educational qualifications, and furthermore, these studies are comparatively scarce within the literature. Hence, it is vital to investigate whether or not the educational qualifications of the $\mathrm{CEO}$ and board members influence firm performance. 
Therefore, the study on family firms which have been managed by the family CEO and non-family CEO in Malaysia, needs to be investigated to find out whether their board educational qualifications play an important role in sustaining their firm performance or otherwise. According to Minichilli, Corbetta, and MacMillan (2010), their study revealed that the family CEO is beneficial for the performance of a family firm. On the contrary, Burkart, Panunzi \& Shleifer (2003) argued that a reliable non-family CEO is vital for the performance of a family firm. Apart from the performance between family firms and non-family firms, there were numerous studies carried out to examine their comparison (Ibrahim \& Lau, 2018; Ibrahim \& Samad, 2011; Miller \& Le Breton-Miller 2006; Villalonga \& Amit 2006; Anderson \& Reeb 2003). Even though family firms contribute significantly to the Malaysian economy and the importance of corporate governance mechanisms on firm performance, research on Malaysian family firms seemed to lag behind. Therefore, there needs to be further research to investigate the emphasis on family firms as family businesses which are governed by family traits, do not exist in other businesses (Mishra et al., 2001).

\section{Literature Review}

\subsection{Altruism and Nepotism in Family Firms}

Altruism is a powerful force within family life and by extension, within the family firm. It ensures that parents are protective of their children, supports family members to be considerate towards each other and cultivates loyalty and commitment to the family and firm. Altruism holds family members together with the firm belief that they have a residual claim on the family estate (Stark \& Falk, 1998). According to agency theory, the agency cost can be reduced through fostering, monitoring and enforcing agreements when ownership goes through the process of aligning interests among family agents towards growth opportunities and risk. Therefore, family agent performance is not monitored regularly. Nevertheless, information asymmetries among family agents can be reduced meanwhile increasing informal agreements usage through increased communication and cooperation within the family firm with altruism (Daily \& Dollinger, 1992). Besides, altruism benefits the agency in a way that creates a heightened sense of interdependence among family agents. In fact, employment relates welfare directly to firm performance. Lubatkin, Schulze, and Dino (2005) stated in their study that altruism is both a blessing and a curse for a family firm because it will give a better chance to enter the family members in the market, and also produce good founders and managers. 
Furthermore, it is deduced that agency problems which grow from altruism and self-control are complicated when the CEO exercise discretion in placing control of the firm's resources. Intrinsically, this broadens the CEO's capacity to make altruistic transfers such as employment, perquisites, and privileges to family members that they would not be receiving if they were employed elsewhere. Henceforth, a variety of agency costs is created when these privileges and the sense of entitlement are evoked (Gersick, Davis, Hampton, \& Lansberg, 1997). Meanwhile, according to Ford and McLaughlin (1986), nepotism is the act of compassion toward one's family members or friends. In economic or employment terms, it can be granting jobs to friends and relatives, without regard to merit. Apparently, such practices impact businesses negatively. In other words, they can erode the support of other employees, reduce the quality and creativity of management and belittle the importance of competence and high-level performance (Zax \& Ichniowski, 1988).

Keles, Ozkan, and Bezirci (2011) conducted a study on Turkish family firms which showed that nepotism, favouritism and cronyism negatively affected the organization's trust in the family business. Nepotism often provides a positive perspective in many smaller family firms. This is due to the practice of "succession" with alternative cheap source of labour. However, according to Zax and Ichniowski, (1988), the practice is misleading where the utmost priority for employment will be competence, only then accompanied by years of constant, superior performance that pave way to succession. Nepotism is neither good nor bad, in and of itself (Barnes \& Hershon, 1976). In other words, nepotism is a neutral phrase. Sarcastically, nepotism reflects the positive or negative charge based on the way one has raised one's children. Generally, the ultimate duty of a parent is to raise responsible adults who have high self-esteem and can function independently in the world (Davis \& Stern, 1981).

The values of becoming competent employees include honesty, integrity, dependability, respect for others, being industrious and doing one's best in every endeavour. These values are crucial to instil in every generation in ensuring that the competent generation is born. On the contrary, the failure of teaching these principles will result in the feeling of entitlement in the children which will lead them to believe that they are privileged and should be given everything. Ironically, the stated deficiency eventually turns into a ripe incubator for problems to emerge when the children works in the family business (Ford \& McLaughlin, 1986).

Children who come to the business with an attitude of entitlement will think they are exempt from the rules that apply to "ordinary people". They often do not understand that they must earn their place in the company through hard work and consistently-demonstrated competence. A seemingly small thing like coming to work on time is an example. Experience has shown that nepotism works if and only if the values of the family members are congruent and the successor 
is fully qualified (Kiechel, 1984). By referring to the literature discussed, it is hypothesized that:

$\mathrm{H}_{1}$ : There is a significant difference between family CEO firms and non-family CEO firms in terms of firm performance.

\subsection{Corporate Governance and Performance}

Corporate governance is a multifaceted concept which has attracted multiple understanding and interpretations; accordingly, there is no general single acceptable definition of corporate governance. Different authors have explained corporate governance differently and associated it with quite a range of corporate issues. Their explanations surround agency relationship and links between corporate governance and the governance of corporations, paying little attention to shareholders' interests.

Gramling and Hermanson (2006) state that corporate governance can be mechanisms that direct and control businesses while conducting the business. Corporate governance is a set of procedures designed to protect shareholders' interests. Due to agency issues, corporate governance has been adopted and has been applied to narrow the gap between shareholders and managers. It also shows that corporate governance studies consists of two categories: using a single component and using multiple components but all focused on the importance of corporate governance (Ng'eni, 2015).

The Malaysian Code on Corporate Governance which was revised in 2007 suggests that directors have certain qualities (skills, knowledge, experience, professionalism, and integrity) in the face of intense responsibility. Previous studies found that board chairman with a university degree is positively associated with seven measures of performance which include earnings per share (EPS), ROA, cumulative returns, cumulative abnormal returns, EPS appreciation, ROA appreciation, and market-to-book ratio. According to Sebora and Wakefield (1998), directors with higher education are well adapted to operations and have business acumen compared to their less-educated counterparts. In addition, Jalbert, Rao, and Jalbert (2002) who studied a sample consisting of Forbes 800 firms discovered that CEOs who graduated from prestigeous schools had a positive relationship with ROA of the firm. Darmadi (2013) found that board of directors with postgraduate education experiences were positively and significantly correlated with ROA. Furthermore, a study conducted by RamónLlorens, Garsía-Meca \& Duréndez (2017) suggested that CEOs who had new information and higher knowledge helped family firms to perform well at the international level.

A study had been conducted on family and non-family firms in Hong Kong to see how highly educated CEOs' work affect the performance of firms. The results were surprisingly different for the firms' performance, as it showed 
that there were more times that the highly educated CEOs became overconfident in making decisions that might have worsened the performance of firms rather than improved them (Ying \& Mie, 2014).

Furthermore, Bhagat et al. (2010) noted that CEOs with MBA degrees performed no better than those without such qualifications. On a side note, empirical evidence from their study revealed that hiring new CEOs with MBAs led to short-term improvement in performance. From the results of the study, Bhagat et al. (2010) did not consider CEO education as a good proxy for CEO ability. Meanwhile, Darmadi (2013) revealed that undergraduate and financial certificates were not significant with ROA. Gottesman and Morey (2006a) found no evidence that CEOs from more prestigious schools outperformed their counterparts from less prestigious schools.

Interestingly, mixed results were found in studies that investigated the influence of graduate degree holders toward better firm performance. Undeniably, educational background and skills were among the determinants of family firm performance (Castillo \& Wakefield, 2006). However, there is a lack of studies conducted on the relationship between the directors' educational qualifications with return on equity (ROE). Based on the given discussion, it is hypothesized that:

$\mathrm{H}_{2}$ :Board degree is significantly and negatively related to the performance of family CEO and non-family CEO firms.

$\mathrm{H}_{3}$ : Board professional qualifications is significantly and negatively related to the performance of family CEO and non-family CEO firms.

Board size refers to the number of directors who serve on the board. Large boards are claimed to be superior to small ones because large groups have more capabilities and resources, and wider networking. Haleblian and Finkelstein (1993) elaborated that large groups could enhance problem-solving abilities by providing more strategic perspectives and constructive judgement. Despite the upside potential, Lipton and Lorsch (1992) came to the conclusion that too many executive members on board would lead to more problems. Furthermore, Darkos and Bekiris (2010) concluded that there is a negative relationship between board size and firm performance, the larger the board size, the lower the firm performance.

Other previous studies also found that small board was more effective than a large one in making executive replacement decisions. Findings by Jensen (1993) revealed that a small board size could increase firm performance. Notably, firms with small board sizes have a higher stock market value (Yermack 1996). Family firms used to have a smaller board size (Ibrahim \& Samad, 2011; Hermalin \& Weisbach, 2003; Eisenberg, Sundgren, \& Wells, 1998; Lipton \& 
Lorsh, 1992; Wald, 1991). According to Bennedsen, Kongsted, and Nielsen (2008), the optimum number for a family firm board size is less than six members. On the negative side, the source of information, experience, and contact of a small board is limited. From the given evidence, it is hypothesized that:

$\mathrm{H}_{4}$ :Board size is significantly and negatively related to the performance of family CEO and non-family CEO firms.

\subsection{Firm Growth and Performance}

The other variable of the study is firm growth due to family businesses as the major GDP contribution in the Malaysian economy (Arman \& Ahmad, 2010). Hitt, Ireland, and Lee (2000) suggested in their study that firm growth depended on knowldge of technology. By understanding and applying technological knowldge, firms are better able to inovate, to lead growth and secure better performance. Furthermore, according to the behavioral theory, managers pay more attention to achieve their goals and attempt to apply aspiration levels to each goal. Evidence from the insurance industry shows that companies grow more when they are below the aspiration level particularly when performance goals are met (Gereve, 2008). Other studies conducted on manufacturing companies in Turkey which investigated the interaction between firm growth and profitability, showed that there was a positive and significant relationship between them (Coban, 2014). By referring to the literature discussed, it is hypothesized that:

$\mathrm{H}_{5}$ : Growth is significantly and positively related to the performance of family $\mathrm{CEO}$ and non-family CEO firms.

\subsection{Ownership Structure and Performance}

Ownership structure is significant towards implementing the corporate governance system for any firm and the country as well. Precisely, the ownership could detect the agency problem whereby the conflict of interest between agents and principals or majority shareholders could be justified. According to Samad (2004), the distribution of power between managers and shareholders is determined by the ownership concentration. Furthermore, according to Hitt, Ireland \& Lee (2000), ownership can be defined as the legal right over the use, disposal and fruits, of means of production indeed in society.

There are various studies on ownership structure and firm performance in Malaysia and globally. According to Demsetz and Lehan (1985), their findings of a relationship between stockholdings by 5 to 10 shareholders and ROE were found to be insignificant. However, Holerness and Sheehan indicated positive correlation between shareholdings and firm performance. Furthermore, based on 
empirical evidence regarding the effects of ownership structure such as insider and blockholders' equity and ownership and firm performance he found that both equity ownership by insiders and blockholders led to better decisions and better firm performance. Gorton and Schmid (2000) noted a strong positive relationship between concentrated equity ownership and firm performance as measured by ROA in Germany.

The empirical evidence showed that the percentage of family ownership or controlled firms was significant to business organizations in the world as revealed in the study by La Porta et al. (1999). Family firms have been defined in various ways by theorists in accordance with studies undertaken at the time. First, they defined family firms based on the degree of ownership and/or management by family members and this was supported by previous studies (Barry, 1975; Barnes \& Hershon, 1976).

Besides, according to empirical studies such as by Sraer and Thesmar (2006) who viewed family controlled firms as firms whose CEOs were either the founder or descendent of the founder. Family firms with paternalism, trust and altruism could bring commitment and love for the business atmosphere (James, 1999). Jensen and Randoy (2003) noted that due to incentive alignment, family enterprises gained possible benefits of reducing agency costs.

Kapopoulos and Lazaretou (2007) mentioned ownership structure firstly as an endogenous variable and secondly as they measured ownership structure which reflected ownership as shareholders with conflicting interests. The results of the study showed that more concentrated ownership showed higher performance. The family-owned firms in China where the family of the higher management originated showed that there was a positive relationship in familyowned firms and the performance of the firms (Goel \& Ramanathan, 2011). There was a negative impact of family-owned firms and its performance and this statement was supported by the research conducted on the Mena region (Ahmed \& Hadi, 2017). Furthermore, if the ownership concentration was low than the firm would perform better but if the concentration of family members was high in the firm's management than there would be a negative impact on the firm's performance. According to Anderson and Reeb (2004), firms with family CEOs performed better than firms having non-family CEOs. By referring to the literature discussed, it is hypothesized that:

$\mathrm{H}_{6}$ :The higher the equity ownership of the family firm, the higher the firm performance.

\section{Methodology}

This section provides information about the study's conceptual model. The operationalization and the measurement of each variable will be discussed. A 
total of 90 listed companies from the various sectors: construction, consumer, property, trading and services which had been listed in Bursa Malaysia from 1999 to 2016 were screened. However, for this study, we took only family firms and grouped them into family CEO and non-family CEO firms. Only 37 companies from the list were family firms, out of which only 21 companies were identified as family CEO firms and 16 companies as non-family CEO firms. The data of the time series and cross-sectional studies were collected from the 37 listed companies in Bursa Malaysia for the period of five years from 2012 to 2016. We defined family firms based on the family ties among the board members and the equity stake held by the family members of at least 20 percent (Ibrahim \& Samad, 2011).

\subsection{Data Source}

Secondary data was the main and only source of data for this study. Most of the secondary data were obtained and manually collected from company annual reports and retrieved from the data stream. By referring to those reports, information such as the number of directors with degree qualifications and professional qualifications could be identified and calculated for the proportion. Furthermore, board size, growth and the percentage of ownership held by the family members were also extracted from the annual reports.

\subsection{Measures}

The response of the dependent variable was predicted, measured and monitored in the event of influence by independent variables (Kuo, Kao, Chang, \& Chiu, 2012). This study employed two profitability ratios as proxy for the performance which were return on equity (ROE) and return on assets (ROA). ROE and ROA were measured based on the net income divided by total shareholders' equity and the net income over the total assets of firms, respectively (Ibrahim \& Samad, 2011).

$$
\begin{aligned}
& \text { Return on Equity (ROE) }=\frac{\text { Net income }}{\text { Total shareholders' equity }} \\
& \text { Return on Assets (ROA) }=\frac{\text { Net income }}{\text { Total assets }}
\end{aligned}
$$

The board size (BSIZE) was measured by the total number of directors who served on the board of the company (Abor \& Biekpe, 2007; Bokpin \& Arko, 2009; Ibrahim \& Samad, 2011). According to Baldwin (1963), a person holding a degree (BDEG) is considered elite in the region of less developed countries. To proxy that qualification, this study considered any undergraduate degree obtained by the board members and CEOs of the listed family firms. Graham and 
Harvey (2002) stated that any individual who holds a postgraduate degree must have first obtained an undergraduate degree. On the other hand, professional qualifications (BPRO) are titles or awards granted by professional bodies. The proportion of directors holding an undergraduate degree qualification and a professional qualification are calculated using the following formulas:

Proportion of directors with degrees $(\mathrm{BDEG}) \quad=\frac{\text { Number of directors with undergraduate degree }}{\text { Total number of board of directors }}$

Proportion of directors with professional qualifications (BPRO)

$=$ Number of directors with professional qualifications Total number of board of directors

Growth opportunities are defined by the annual percentage change of total assets (Pandey, 2001; Pandey, 2004; Eriotis, Vasilious, \& Ventoura Neokosmidi, 2007; Abor \& Biekpe, 2009; Karadeniz Kandir, Balcilar, \& Onal, 2009; Chadha \& Sharma, 2015; Ahsan, Wang, \& Qureshi, 2016; Ohman \& Yazdanfar), as shown by:

Growth $=\frac{\left(\sum T A_{1}-\sum T A_{0}\right)}{\sum T A_{0}} X 100$

The percentage of equity held by managers is measured using the sum of their direct and indirect share ownership and their stock options outstanding plus share ownership by their immediate families. In this study, family ownership (OWNSHP) was measured by taking the percentage of equity stake held by family members of at least 20 percent.

Control variables are also defined as a constant variable. In scientific experimentations, this variable is the experimental element that stays constant and unchanged throughout the investigation in order to test the relative relationship of the dependent and independent variables. Many previous studies used firm size (LNFSIZE) and Leverage or debt ratio (DR) as control variables. In this study, the firm size was measured by the natural log of total assets of the company (Ibrahim \& Samad, 2011; Sheikh \& Wang, 2012; Vakilifard, Gerayli, Yanesari, \& Ma'atoofi, 2011) and debt ratio was measured by total debt divided by total assets (Friend and Lang, 1998).

Leverage $(\mathrm{DR})=\frac{\sum \text { Total Debt }}{\sum \text { Total Assets }}$

\subsection{Panel Data of Multiple Regression Analysis}

This study employed the panel data approach as it eliminated unobservable heterogeneity that different firms in the sample data could present, less collinearity 
among the variables and a better measurement than pure cross-section or pure time-series data (Baltagi, 2001; Gujarati, 2003). Panel data analysis enabled the study to consider both time series and cross-sectional effects as it used the collection of observations of cross-section data over several time series.

\subsection{Model Selection}

Model selection is presented as follows:

$$
\begin{aligned}
\text { PERF }= & \alpha+\beta_{1} \text { BDEG }_{\text {it }}+\beta_{2} \text { BPRO }_{i t}+\beta_{3} \text { BSIZE }_{\text {it }}+\beta_{4} \text { GROWTH }_{i t} \\
& +\beta_{5} \text { OWNSHP }_{i t}+\beta_{6} \text { LEV }_{i t}+\beta_{7} \text { LNFS }_{i t}+\varepsilon_{i t}
\end{aligned}
$$

where:

PERF $=$ Return on assets $(\mathrm{ROE})$, Return on equity $(\mathrm{ROE})$

$\mathrm{BDEG}=$ Proportion of directors with undergraduate degrees

$\mathrm{BPRO}=$ Proportion of directors with professional qualifications

BSIZE $=$ Board size

GROWTH $=$ Growth

OWNSHP = Ownership

$\mathrm{LEV}=$ Debt ratio

LNFS $=$ Firm size

$\varepsilon i t=$ The Disturbance or Error Term

\section{Analysis of Results}

Table 1 shows the descriptive statistics of the full sample, family CEO and nonfamily CEO firms from 2012 to 2016 . The findings demonstrated that firm size was larger for non-family CEO firms compared to family CEO firms. Similarly, non-family CEO firms had higher mean performance ratios for both ROE and ROA compared to family CEO firms. As a summary, non-family CEO firms had a slightly smaller mean in board size (7.725), a higher proportion of board degrees (0.547), and a slightly higher proportion of board professional qualification (0.359), compared to family CEO firms.

Independent samples t-test results showed that there was only mean proportion of board professional qualifications which was significantly different between family CEO and non-family CEO firms where non-family CEO had a higher mean (0.353) compared to family CEO firms $(0.279)$ at 5 percent level as presented in Table 2. This finding was consistent with Burkart et al. (2003) where non-family CEO firms with higher board professional qualifications gained significant reliability to perform better than family CEO firms. Likewise, it was also consistent with the study carried out by Sebora and Wakefield (1998), where firm performance were higher as more educated directors were on the board. 


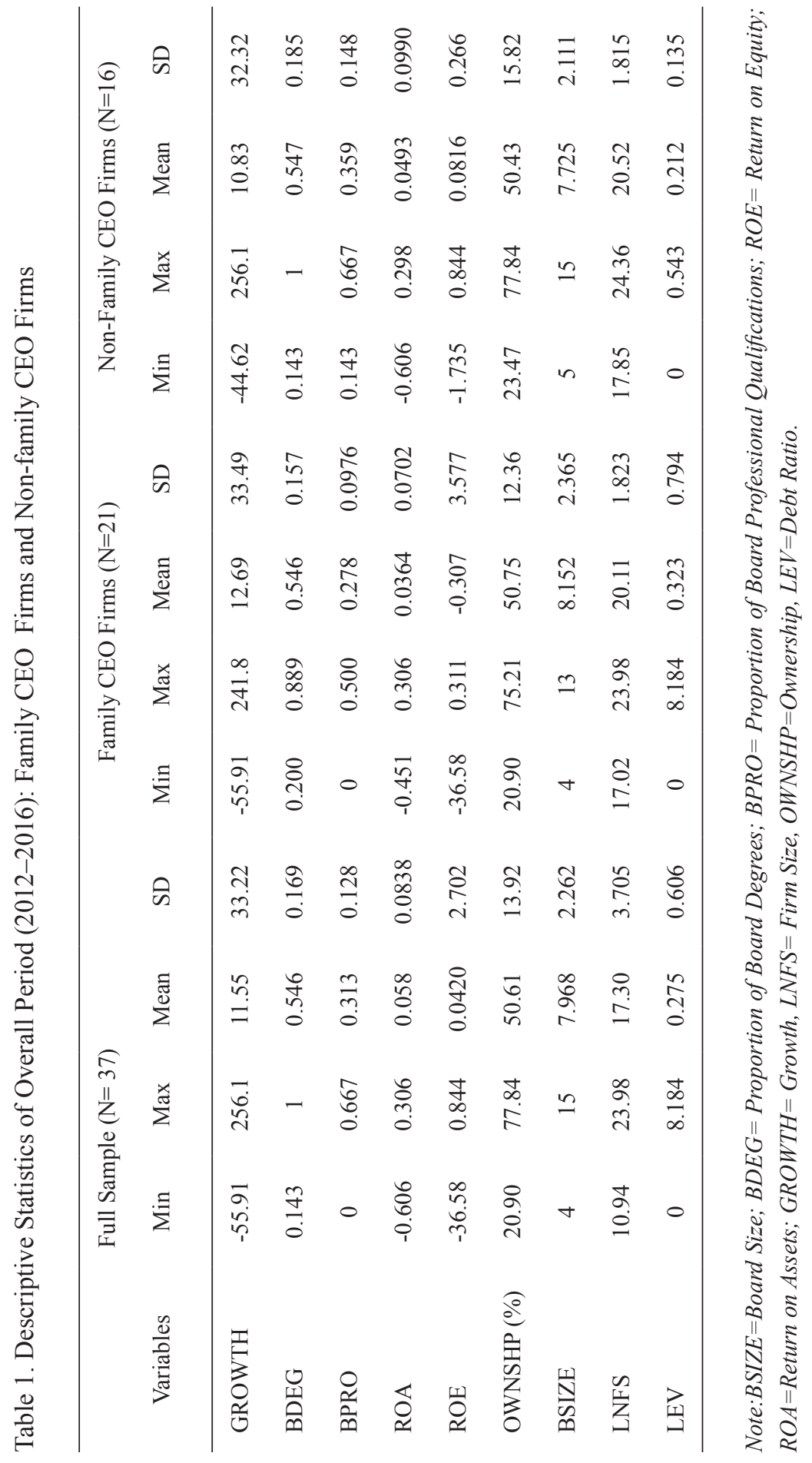


Table 2. Differences in Means Tests

\begin{tabular}{lccc}
\hline Variable & $\begin{array}{c}\text { Family CEO Firms } \\
\text { Mean }\end{array}$ & $\begin{array}{c}\text { Non-family CEO Firms } \\
\text { Mean }\end{array}$ & t-stat \\
\hline BDEG & 0.546 & 0.552 & -0.128 \\
BPRO & 0.279 & 0.353 & $-1.943^{* *}$ \\
ROE & 0.039 & 0.082 & -0.871 \\
ROA & 0.035 & 0.050 & -0.734 \\
LNFS & 20.176 & 20.544 & -0.632 \\
\hline
\end{tabular}

*** significant at 0.01 level ** significant at 0.05 level * significant at 0.10 level Note:BSIZE=Board Size; $B D E G=$ Proportion of Board Degrees; $B P R O=$ Proportion of Board Professional Qualifications; ROE = Return on Equity; ROA=Return on Assets; GROWTH= Growth, LNFS=Firm Size, OWNSHP=Ownership, LEV=Debt Ratio.

Table 3. The Pearson's Correlation Coefficients of the Study Variables

\begin{tabular}{clllllllll}
\hline & ROA & ROE & BSIZE & BDEG & BPRO & LNFS & OWNSHIP & GROWTH & LEV \\
\hline ROA & 1 & & & & & & & & \\
ROE & $0.705^{* * *}$ & 1 & & & & & & & \\
BSIZE & 0.0342 & 0.137 & 1 & & & & & & \\
BDEG & -0.0498 & -0.0376 & 0.0683 & 1 & & & & & \\
BPRO & -0.0451 & -0.122 & 0.109 & -0.167 & 1 & & & \\
LNFS & $0.251^{* *}$ & 0.127 & $0.494^{* * *}$ & $0.274^{* *}$ & 0.165 & 1 & & & \\
OWNSHP & 0.114 & -0.0255 & -0.122 & -0.0517 & -0.0202 & 0.145 & 1 & & \\
GROWTH & 0.140 & 0.0407 & -0.0152 & 0.0300 & 0.0359 & 0.0720 & 0.179 & 1 & \\
LEV & -0.0619 & -0.00284 & 0.0317 & 0.125 & -0.133 & -0.00472 & -0.0756 & 0.00422 & 1 \\
\hline
\end{tabular}

${ }^{*} p<0.05,{ }^{* *} p<0.01,{ }^{* * *} p<0.001$

Note:BSIZE=Board Size; $B D E G=$ Proportion of Board Degrees; $B P R O=$ Proportion of Board Professional Qualifications; ROE= Return on Equity; ROA=Return on Assets; GROWTH= Growth, LNFS=Firm Size, OWNSHP=Ownership, LEV=Debt Ratio.

Table 3 shows that ROE is positively and highly correlated to ROA at 1 percent level indicating that these two variables have strong correlation with each other as it is still in the acceptable level. In conclusion, larger board size, higher ROE and higher ROA are important complementary factors when firm size is larger.

Table 4 shows the findings of the study which indicates that the proportion of board professional qualifications (BPRO) is negative and significant at 1 percent level for full sample and family CEO firms with ROE. This proved that a higher proportion of board professional qualifications would reduce the impact on ROE. This was consistent with the findings by Bhagat et al. (2010) where they 
did not consider CEO education as a good proxy for CEO ability in long-term firm performance. In addition, firm size (LNFS) had a positive and significant relationship with ROE at 0.01 level This proved that larger firm size as control variable with a significance of 1 percent in this sample influenced ROE in the positive direction which was consistent with previous studies (Ang \& Ding, 2005; Mcknight \& Mira, 2003). With regard to growth, there was a positive and significant relationship between growth and firm performance which was consistent with findings by Arman and Ahmad (2010) who stated that growth would influence firm performance thus contributing to the GDP of the country as exhibited in Table 4 and Table 5.

Table 4. Regression Results for Return on Equity (ROE)

\begin{tabular}{llll}
\hline \multicolumn{1}{c}{ Variable } & Full Sample $(\mathrm{N}=37)$ & \multicolumn{1}{c}{$\begin{array}{c}\text { Family CEO } \\
\text { Firms }(\mathrm{N}=21)\end{array}$} & $\begin{array}{c}\text { Non-Family CEO Firms } \\
(\mathrm{N}=16)\end{array}$ \\
\hline Intercept & $-38.20 * * *(10.91)$ & $-61.56 * * *(21.86)$ & $-1.029 *(0.583)$ \\
BSIZE & $-0.353(0.419)$ & $-0.330(0.764)$ & $0.0007(0.0248)$ \\
BDEG & $1.175(2.473)$ & $0.896(4.519)$ & $-0.285(0.229)$ \\
BPRO & $-13.32 * * *(3.805)$ & $-21.54 * * *(8.143)$ & $0.0324(0.293)$ \\
LNFS & $2.570 * * *(0.620)$ & $3.447 * * *(1.076)$ & $0.0638 * *(0.0312)$ \\
OWNSHP & $-0.000651(0.0356)$ & $0.00294(0.0484)$ & $-0.00182(0.00377)$ \\
GROWTH & $-0.000575(0.00645)$ & $0.000035(0.0113)$ & $0.00135 *(0.000807)$ \\
LEV & $-0.0768(0.345)$ & $-0.0846(0.452)$ & $0.0816(0.342)$ \\
OBSERVATION & 185 & 105 & 80 \\
R-SQUARED & 0.160 & 0.221 & 0.1443 \\
\hline
\end{tabular}

Standard errors in parentheses

$* * * p<0.01, * * p<0.05, * p<0.1$

Note:BSIZE=Board Size; $B D E G=$ Proportion of Board Degrees; $B P R O=$ Proportion of Board Professional Qualifications; ROE= Return on Equity; ROA=Return on Assets; GROWTH= Growth, LNFSIZE $=$ Firm Size, OWNSHP=Ownership, LEV=Debt Ratio.

Meanwhile, Table 5 shows that the relationship between ROA and firm size is positive and significant at 0.01 level for all samples which confirms that the larger the size of the firm, the likelihood that it will increase the performance of the firm. Furthermore, the relationship between board degrees and ROA was negative and significant at $10 \%$ level only for full sample. This result was supported by Bhagat et al. (2010) who found that CEOs who were degree holders performed no better than those without such qualifications. Gottesman and Morey (2006a) also stated that there was no evidence that CEOs from more prestigious schools outperformed their counterparts from less prestigious schools. Another study conducted by Adnan et al. (2016) on government linked companies and non- 
government linked companies in Malaysia showed similar results, that diversity in education was not associated with better firm performance. The results of study did not show any significant relationship between firm performance and the education level of the board of directors.

Table 5. Regression Results for Return on Assets (ROA)

\begin{tabular}{llll}
\hline \multicolumn{1}{c}{ Variable } & \multicolumn{1}{c}{$\begin{array}{c}\text { Full Sample } \\
(\mathrm{N}=37)\end{array}$} & $\begin{array}{c}\text { Family CEO Firms } \\
(\mathrm{N}=21)\end{array}$ & \multicolumn{1}{c}{$\begin{array}{c}\text { Non-Family CEO } \\
\text { Firms }(\mathrm{N}=16)\end{array}$} \\
\hline Intercept & $-1.087 * * *(0.271)$ & $-0.260^{* *}(0.125)$ & $-0.416^{*}(0.223)$ \\
BSIZE & $-0.0112(0.0104)$ & $-0.0067(0.0053)$ & $-0.00196(0.0094)$ \\
BDEG & $-0.110 *(0.0615)$ & $-0.0586(0.0579)$ & $-0.0938(0.0848)$ \\
BPRO & $-0.0823(0.0946)$ & $-0.0948(0.0961)$ & $0.0503(0.109)$ \\
LNFSIZE & $0.0757 * * *(0.0154)$ & $0.0202 * * *(0.0072)$ & $0.0251^{* *}(0.0119)$ \\
OWNSHP & $-0.00012(0.0009)$ & $0.000059(0.0007)$ & $-0.0003(0.0014)$ \\
GROWTH & $0.00019(0.00016)$ & $0.00016(0.0002)$ & $0.00049 *(0.0003)$ \\
DR & $-0.0043(0.0086)$ & $-0.00387(0.0076)$ & $0.0398(0.128)$ \\
& & & \\
OBSERVATION & 185 & 105 & 80 \\
R-SQUARED & 0.166 & 0.1115 & 0.1396 \\
\hline
\end{tabular}

Standard errors in parentheses

$* * * p<0.01, * * p<0.05, * p<0.1$

Note:BSIZE=Board Size; $B D E G=$ Proportion of Board Degrees; $B P R O=$ Proportion of Board Professional Qualifications; ROE= Return on Equity; ROA=Return on Assets; GROWTH= Growth, LNFSIZE = Firm Size, OWNSHP=Ownership, LEV=Debt Ratio.

\section{Conclusion}

This study shows that board professional qualifications is negative but significantly related to return on equity (ROE) of family CEO firms. Board qualifications as proxied by only the proportion of board professional qualifications significantly decreased the performance of family CEO firms. This indicated that professional qualifications is less important in improving the performance of a family CEO firm externally (ROE) rather than internally (ROA). Interestingly, there is a significant difference in the proportion of board professional qualifications between family CEO firms and non-family CEO firms. This confirms the presence of altruism and nepotism practices among family members and supports the argument of nepotism characteristics such as granting jobs to friends and relatives regardless of merit. Firm size shows a positive and significant relationship with both ROE and ROA at level 0.01 , confirming that a larger size firm contributes to an increase in firm performance. 
These significant findings can contribute to the advancement of knowledge especially in the importance of board education among directors for better firm performance. As for board qualifications tested in this study, it is divided into board degrees and board professional qualifications by proportion. The results indicated that there is significance but in a negative direction for board professional qualifications among family board members showing that the family members are less concerned with seeking board degrees or professional qualifications to improve their businesses. It was as though the business would be automatically passed down from one generation to the next without consideration for educational background. It is vital that apart from experience, directors are knowledgeable and possess recognized board degrees and/or professional qualifications which collectively contribute toward the expertise or competitive advantage for the firm. Flexibility in business acumen can be achieved with in-depth knowledge in the business, especially in accounting and finance. It is encouraged that family CEO firms and non-family CEO firms emphasize the importance of board qualification as previous studies have proven its significance in elevating firm growth and performance .

\section{Acknowledgements}

The first author would like to thank Universiti Sains Malaysia for the bridging grant no. 304.PMGT.6316293.

\section{References}

Abor, J., \& Biekpe, N. (2007). Corporate governance, ownership structure and performance of SMEs in Ghana: Implications for financing opportunities. Corporate Governance, 7(3), 288-300.

Adnan, M. F., Sabli, N., Rashid, M. Z. A., Hashim, A., Paino, H., \& Abdullah, A. (2016). The impact of educational level of board of directors on firms' performance. Regional Conference on Science, Technology and Social Sciences (RCSTSS 2014), 37-48. doi:10.1007/978-981-10-1458-1_4

Ahmed, N., \& Hadi, O. A. (2017). Impact of ownership structure on firm performance in the MENA region: An empirical study. Accounting and Finance Research, 6(3).

Ahsan, T., Wang, M., \& Qureshi, M.A. (2016) Firm, industry, and country level determinatns of capital structure: Evidence from Pakistan. South asianJournal of Global Business Research,5(3), 362-384.

Amran N. A., \& Ahmad, A. C. (2010). Family succession and firm performance among Malaysian companies. International Journal of Business and Social Science, 1(2), 193 - 203. 
Anderson, R. C., \& Reeb, D. M. (2003). Founding-family ownership and firm performance: Evidence from the S\&P 500. The Journal of Finance, LVIII, (3), 1301-1328.

Anderson, R. C., \& Reeb, D. M. (2004). Board composition: Balancing family influences in S\&P 500 Firms. Administrative Science Quarterly, 49(2), 209-237.

Ang, J. S. \& Ding, D.K. (2006). Government ownership and the performance of government linked companies: The case of Singapore. Journal of Multinational Financial Management, 16(1), 64-88.

Baldwin, R. (1963). Depreciation for non-profit organizations - An opposing view. The New York Certified Public Accountant (August 1963), 549557.

Baltagi, B. (2001). Econometric analysis of panel data (2nd ed.). Chichester: John Wiley and Sons.

Barnes, L. B., \& Hershon, S. A. (1976). Change management: Transferring power in the family business. Harvard Business Review, 1976 Issue, 1-26.

Barry, B. (1975). The development of organization structure in the family firm. Journal of General Managment, 3, 42-60.

Bennedsen, M., Kongsted, H. C., \& Nielson, K. M. (2008). The causal effect of board size in the performance of small and medium-sized firms. Journal of Banking and Finance, 32, 1098-1109.

Bhagat, S., Bolton, B., \& Subramanian, A. (2010, 3 August). CEO education, CEO turnover, and firm performance. Working paper, University of Colorado, Boulder.

Bokpin, G. A., \& Arko, A.C. (2009). Ownership structure, corporate governance and capital structure decisions of firms, empirical evidence from Ghana. Economics and Finance, 26(4), 246-256.

Burkart, M., Panunzi, F., \& Shleifer, A. (2003). Family Firm. Journal of Finance, The Journal of the American Finance Association, 58(5), 2167-2202.

Castillo, J., \& Wakefield, M. W. (2006). An exploration of firm performance factors in family businesses: Do families value only the "bottom line". Journal of Small Business Strategy, 17(2), 37 -51.

Chadha, S., \& Sharma, A. K. (2015). Determinants of capital structure : An emperical evaluation from India. Journal of advances in Managment Research, 12(1), 3-14.

Claessens, S., Djankov, S., \& Lang, L. H. P. (2000). The separation of ownership and control in East Asian corporation. Journal of Financial Economics, $58,81-112$.

Coban, S. (2014). The interaction between firm growth and profitability: Evidence from Turkish (Listed) manufacturing firms. The Journal of Knowledge Economy \& Knowledge Management, 9, 41-50.

Daily, C. M., \& Dollinger, M. J. (1992). An empirical examination of ownership structure in family and professionally managed firms. Family Business Review, 5(2), 11-34. 
Darkos, A. A., \& Bekiris, F. V. (2010). Corporate performance, managerial ownership and endogeneity: A simultaneous equations analysis for the Athens stock exchange. Research in International Business and Finance, 24(1), 24-38.

Darmadi, S. (2013). Board members' education and firm performance: Evidence from a developing economy. International Journal of Commerce and Management, 23(2), pp. 113-135.

Davis, P., \& Stern, D. (1981) Adaptation, survival, and growth of the family business: An integrated systems perspective. SAGE Journals, Family business Review. 1(1), 1-99.

Demsetz, H., \& Lehan, K. (1985). The structure of corporate ownership: Causes and consequences. Journal of Political Economy, 93(6), 1155-1177.

Eisenberg, T., Sundgren, S., \& Wells, M. (1998). Larger board size and decreasing firm value in small firms. Journal of Financial Economics, 48, 35-54.

Eriotis, N., Vasiliou, D., \& Neokosmidi., Z. V. (2007). How firms characteristics affect capital structure: An empirical study. Managerial Finance, 33(5), 321-331.

Faccio, M., Lang, L., \& Young, L. (2002). Dividends and expropriation. American Economic Review, 91, 54-78.

Filatotchev, I., Lien, Y-C., \& Piesse, J. (2005). Corporate governance and performance in publicly listed, family-controlled firms: Evidence from Taiwan. Asia Pacific Journal of Management, 22(3), 257-283.

Ford, R., \& McLaughlin, F. (1986). Nepotism: Boon or bane. Personnel Administrator, 31(11), 78-89.

Friend, I., \& Lang, L. H. P. (1988). An empirical test of the impact of managerial self-interest on corporate capital structure. Journal of Finance, 43, 217 281.

Gersick, K. E., Davis, J. A., Hampton, M. M., \& Lansberg, I. (1997). Generation to generation: Life cycles of the family business. Harvard Business School Press. United States of America.

Goel, M., \& Ramanathan, P. E. (2014). Business ethics and corporate social responsibility- Is there a dividing line? Procedia Economics and Finance, 11, 49-59.

Gorton, G., \& Schmid, F. (2000). Class struggle inside the firm: A stud of German codetermination. NBER Working Paper No. 7945, October 2000.

Gottesman, A. A., \& Morey, M. R. (2006a). Does a better education make for better managers? An empirical examination of CEO educational quality and firm performance. Working paper, Pace University, New York, 21 April (2004).

Gottesman, A. A., \& Morey, M. R. (2006b). Manager education and mutual fund performance. Journal of Empirical Finance, 13(2), 145-182.

Graham, J. R., \& Harvey, C. (2002). How do CFOs make capital budgeting and capital structure decisions. Journal of Applied Corporate Finance, Spring, pp. 8-23. 
Gramling, A. A., \& Hermanson, D. R., (2006), What roles is your internal audit function playing in corporate governance? Internal Auditing, 21(6), 37

Greve, B. (2008). Risk and welfare. Social Policy and Administration, 42(6), 710-713.

Gujarati, N. D. (2003). Basic econometrics (4th ed.). Singapore:McGraw.

Hill. Haleblian, J., \& Finkelstein, S. (1993). CEO succession and stockholder reaction: The influence of organisational context and event content. Academy of Management Journal, 36(3), 544-563.

Hermalin, B. E., \& Weisbach, M. S. (2003). Boards of directors as an endogenously determined institution: A survey of the economic literature. Economic Policy Review, April, 7-25.

Hitt, M. A., Ireland, R. D., \& Lee, H. (2000). Technological learning, knowledge management, firm growth and performance: An introductory essay. Journal of Engineering and Technology Management, 17(3-4), 231246.

Holderness, C. G., \& Sheehan, D. P. (1988). The role of majority shareholders in publicly held corporations: An explanatory analysis. Journal of financial Economics, 20(1-2), 317-346.

Ibrahim H., \& Samad. F. M. (2011). Corporate governance and agency costs. In Kose John, Anil K. Makhija (Ed.), International Corporate Governance Advances in Financial Economics, 14, 09-130.

Ibrahim, H., \& Lau, T. C. (2018). Capital structure and firms determinants: Evidence from surviving family and non-family listed companies in Malaysia, Asia Conference on Business and Economic Studies (ACBES 2018), University of Economics Ho Chi Minh City, Ho Chi Minh City, Vietnam on 8-9 September 2018.

Jalbert, T., Rao, R., \& Jalbert, M. (2002). Does school matter? An empirical analysis of CEO education, compensation and firm performance. International Business and Economics Research Journal, 1(1) Winter, 83-98.

James, H. S. Jr. (1991). Owner as manager: Extended horizons and family firm. International Journal of Economics of Business, 6(1), 41-55.

Jensen, J. I., \& Randoy, T.(2003). Family firms and good corporate governance: Altruism and agency consideration. Paper presented at the Europen Acedmey of Managment Meeting, September 2003, Milan, Itlay.

Jensen, M. C. (1993). The modern industrial revolution, exit, and the failure of internal control systems. Journal of Finance, 48, 831-880.

Kapopoulos, P., \& Lazaretou, S. (2007). Corporate ownership structure and firm performance: Evidence from greek firms. Journal of Corporate Governance, 15(2), 144-158.

Karadeniz, E., Kandir, S. Y., Balcilar, M., \& Onal, Y. B.(2009). Determinanats of capital structure: Evidence form Turkish lodging companies. International Journal of Contemporary Hospitality Managment, 21(5), 594-609. 
Keles, H. N., Ozkan, T. K., \& Beziric, M. (2011) A study on the effect of nepotism, favoritism and cronyism on organizational trust in the auditing process in family buisness in Turkey. International Buisness \& Economic Research Journal, 10(9), 9-16.

Kiechel, W. (1984) To cpmpute or not to compute: Why executives don't: stop feeling guilty -it may be that the technology wonder has, a yet, little to offer you. SAGE Journal Cornell Hotle and Administration Quartely, 24(4) 9-11.

Kuo, A., Kao, M. S., Chang, Y. C., \& Chiu, C. F (2012). The influence of international experience on entry mode choice: Difference between family and non-family firms. European Management Journal, 30(3), 248-263.

La Porta, R. Lopez-De-Silances, F., \& Shliefer, A. (1999). Corporate ownership around the world. The Journal of Finance, Vol. LIV, No. 2, 471-517.

Lipton, M., \& Lorsch, J. (1992). A modest proposal for improved corporate governance. Business Lawyer, 48, 59-77.

Lubatkin, M. H., Schulze, W. S., \& Dino, R. N. (2005). The effect of parental altruism on the governance of family managed firms. Journal of Organizational Behaviour, 26, 313-330.

Malaysian Code on Corporate Governance. (2012). Security Commission Malaysia. doi.http://www.sc.com.my/malaysian-code-on-corporategovernance-2012/

McKnight, P. J. \& Mira, S. (2003). Corporate governance mechanisms, agency costs and firm performance in UK firms, http://ssrn.com/ abstract $=460300$

Miller, D., \& Le Breton-Miller, I. (2006). Family governance and firm performance: Agency, stewardship, and capabilities. Family Business Review, 19(1), 73-87.

Minichilli, A., Corbetta, G., \& MacMillan, I. C. (2010). Top management teams in family-controlled companies: 'Familiness', 'faultlines' and their impact on financial performance. Journal of Management Studies, 47(2), 205-222.

Mishra, C. S., Randoy, T., \& Jenssen, J. I. (2001). The effect of founding family influence on firm value and corporate governance. Journal of International Financial Management and Accounting, 12(3), 235-259.

Ng'eni, F.B. (2015). The corporate governance and firm performance: A review of existing empirical evidence. European Journal of Business and Management, 7(33), 22-35.

Ohman, P., \& Yazdanfar, D. (2017). Short and long term debts in Swedish SMEs. Review of Accounting and Finance, 16(1), 106-124.

Pandey, I.M (2001). Corporate dividend policy and behaviour: The Malaysian experince. IIMA Working Paper No. 2001-11-01. 
Pandey, I.M.(2004). Capital Structure,Profitability and Market Structure: Evidence from Malaysia.The Pacific Journal of economics, 8(2), 7891.

Ramón-Llorens, M. C., García-Meca, E., \& Duréndez, A. (2017). Influence of CEO characteristics in family firms internationalization. International Business Review, 26(4), 786-799.

Samad, F.A. (2004). Corporate governance and ownership structure in the Malaysian corporate sector. Advances in Financial Economics, 9, $355-$ 385.

Sebora, T. C., \& Wakefield, M. W. (1998). Antecedents of conflict or business issues in family firms. Journal of Entrepreneurship Education, 1, 2-18.

Sheikh, N. A., \& Wang, Z. (2012). Effects of corporate governance on capital structure: empirical evidence from Pakistan. Corporate Governance, 12(5), 629-641.

Sraer, D.A., \& Thesmar, D. (2006). Performance and behaviour of family firms: Evidence from the French stock market. ECGI Finance Working paper No. 130/2006

Stark, O., \& Falk, I. (1998). Transfers, empathy formation, and reverse transfers. The American Economic Review, 88(2), 271-276.

Ujunwa, A., Nwakoby, I., \& Ugbam, C.O. (2012). Ccorporate board diversity and firm performance: Evidence from Nigeria. Corporate Ownership and Control, 9(2), 216-223.

Vakilifard, H. R., Gerayli, M. S., Yanesari, A. M., \& Ma’atoofi, A. R. (2011). Effect of corporate governance on capital structure: case of the Iranian listed firms. European Journal of Economics, Finance and Administrative Sciences, 35, 165-172.

Villalonga, B., \& Amit, R. (2006). How do family ownership, control and management affect firm value? Journal of Financial Economics, 80, 385-417.

Wald, J. K. (1999). How firm characteristics affect capital structure: An international comparison. Journal of Financial Research, 22, 161-187.

Yermack, D. (1996). Higher Market Valuation of Companies with a Small Board of Directors. Journal of Financial Economics, 40, 185-211.

Ying, C.H., \& Mie, Y.C. (2014). CEO education and firm performance. Evidence from Hong Kong (Unpublished Dissertasion Degree Project Proposal). Submitted to the School of Business in Partial Fulfilment.

Zax, J. \& Ichniowski, C. (1988). The effects of public sector unionism on pay, employment, department budgets, and municipal expenditures. In: Freeman, R. B. and Ichniowski, C. (Eds), When public sector workers unionize. University of Chicago Press, 323 - 364. ISBN: 0-226-26166-2 